\title{
Construction and Potentiometric Study of Chloramphenicol Selective Electrodes Based on a PVC Matrix Membrane
}

\author{
Yasmeen H. Muhamad \\ Department of Chemistry, College of Science, Baghdad University, Al-Jaderia, Baghdad-Iraq.
}

\begin{abstract}
Chloramphenicol succinate selective electrodes were prepared based on a complex Chloramphenicol succinate -phosphomolybdate as an active material using the plasticizers di-octyl phthalate (DOPH), tri-butyl phosphate (TBP), o-nitro phenyl octyl ether (ONPOE) and di-butyl phthalate (DBPH) in a PVC matrix membrane. The properties of the prepared electrodes were studied, such as: slope, concentration range, detection limit, lifetime, $\mathrm{pH}$ effect and selectivity. The experimental results showed that the best electrode was based on DOPH and DBPH as plasticizers, displaying a linear range from $1.00 \times 10^{-4} \mathrm{M}$ to $1.00 \times 10^{-1} \mathrm{M}$ and $1.00 \times 10^{-1} \mathrm{M}$ to $2.00 \times 10^{-4}$ with a Nernstian slope of $58.5 \mathrm{mV} /$ decade and $53.9 \mathrm{mV} /$ decade, correlation coefficient of 0.9999 and 0.9998 , The detection limit was $5.5 \times 10^{-5} \mathrm{M}$ and $8.0 \times 10^{-5}$, the lifetime was around 40 and 25 days respectively. The proposed electrodes were successfully applied to the determination of in Chloramphenicol succinate a pharmaceutical preparation.
\end{abstract}

Keyword: Chloramphenicol; Ion-selective electrode; Potentiometry; Pharmaceutical analysis.

\section{Introduction}

Chloramphenicol (CAP) is 2,2 dichloro$\mathrm{N}-[(1 \mathrm{R}, 2 \mathrm{R})-2-$ hydroxy-1-hydroxymethyl-2-(4nitrophenyl)ethyl]acetamide, $\quad \mathrm{C}_{11} \mathrm{H}_{12} \mathrm{C}_{12} \mathrm{~N}_{2} \mathrm{O}_{5}$, whereas its chemical structure is:<smiles>O=C(NC(CO)[C@H](O)c1ccc([N+](=O)[O-])cc1)C(Cl)Cl</smiles>

Its molecular weight is $323.1 \mathrm{~g}$ mol-1, It is a white, greyish-white or yellowish-white, fine crystalline powder or fine crystals, needles or elongated plates, freely soluble in methanol, ethanol, butanol, ethyl acetate, acetone, and in propylene glycol, slightly soluble in water, and ether, insoluble in benzene, and petroleum ether, it melts at $150.5-151.5^{\circ} \mathrm{C}$ [1].

Chloramphenicol is a bacteriostatic antimicrobial. It is considered a prototypical broad-spectrum antibiotic, alongside the tetracyclines. Chloramphenicol is effective against a wide variety of Gram-positive and Gram-negative bacteria, including most anaerobic organisms. It is widely used because it is inexpensive and readily available [2].

The toxicity of chloramphenicol is derived from its action on the mitochondrial synthesis of proteins and can cause serious secondary effects [3]. The officially recommended methods in pharmacopoeias for determining chloramphenicol are scarcely selective as they rely on direct measurements of the absorbance at $276 \mathrm{~nm}$ of an aqueous solution of the drug. The AOAC-endorsed method for nitro compounds involves reduction in a column packed with powdered zinc metal and subsequent reaction with ammonium sulphamate and $\mathrm{N}$-naphthylethylene diamine [4].

The determination of chloramphenicol has also been addressed by using various titrimetric [5] and spectrophotometric methods other than those based on reduction of the nitro group and the Griess reaction [6-8].

Despite concern about its toxicity chloramphenicol is widely used to treat neonatal meningitis. Three types of toxicity have been described-namely, the grey baby syndrome [9] reversible dose related haemopoietic disturbances [10] and idiopathicmarrow aplasia unrelated to dosage [11]. Serum chloramphenicolcon centrations between 40 and $200 \mathrm{mg} / \mathrm{l}$ have been reported in association with the grey syndrome [12-14].

\section{Experimental Part Equipments}

An expandable ion analyzer (WTW model, Germany), a pH meter (WTW model pH 720, 
Germany), and a saturated calomel electrode (Gallenkamp, USA) were used in this work.

\section{Reagents and Solutions}

1-Standard Chloramphenicol sodium succinate (CPSS) supplied from (Samara IRAQ-SDI).

2- Chloramphenicol sodium succinate (CPSS) injection (1.00 g) made in (HumbergGermany) and tablet $(1.00 \mathrm{~g})$ made in Pfizer Company, USA) were purchased locally.

3-Di-octyl phthalate 98.9\% (DOPH). was obtained from Fluka AG, Switzerland.

4- Tri-n-butyl phosphate 97\% (TBP) was obtained from Fluka AG, Switzerland.

5- O-nitrio phenyl octyl ether 98\% (ONPOE) was obtained from Fluka AG, Switzerland.

6-Di-n-butyl phthalate 99\% (DBPH) was obtained from Fluka AG, Switzerland.

7- Stock solutions of $0.1 \mathrm{M}$ for each of $\mathrm{LiCl}$, $\mathrm{NaCl}, \mathrm{KCl}, \mathrm{CaCl} 2, \mathrm{MgCl} 2, \mathrm{ZnCl} 2, \mathrm{FeCl} 3$, $\mathrm{AlCl} 3$, and $\mathrm{CrCl} 3$ were prepared. More diluted solutions were prepared by subsequent dilution of the stock solutions.

8-A solution of $0.1 \mathrm{M}$ Chloramphenicol succinate was prepared by dissolving $2.226 \mathrm{~m} \mathrm{~g}$ of standard and making the solution up to $50 \mathrm{~mL}$ with deionized water.

9- A $0.05 \mathrm{M}$ potassium hydrogenphthalate buffer solution $(\mathrm{pH} 4.00)$ was prepared by dissolving $10.21 \mathrm{~g}$ of solid potassium hydrogen phthalate in $1 \mathrm{~L}$ of deionized water after adjusting the $\mathrm{pH}$.

\section{Procedure}

\section{Preparation of ion-pair compound}

CPPS-PMA ion-pair was prepared by mixing $50 \mathrm{~mL}$ of $0.01 \mathrm{M}$ Chloramphenicol succinate with $50 \mathrm{~mL}$ of $0.01 \mathrm{M}$ phosphomolybdic acid while stirring. The resultant precipitate was filtered, washed with deionized water, and dried at $60 \circ \mathrm{C}$.

\section{Assembly of ion-selective electrodes}

The construction of the electrode body and the immobilization were done as described by (Craggs et al. 1974). [15]

The glass tube was $3 / 4$ filled with $0.1 \mathrm{M}$ Chloramphenicol succinate solution as an internal filling solution. The membrane was conditioned by immersing in a standard solution of $0.1 \mathrm{M}$ for at least $2 \mathrm{hrs}$. before measurements. Calibration curves were prepared by plotting the potential versus the concentration of Chloramphenicol succinate. The $\mathrm{pH}$ of $10^{-4}, 10^{-3}$ and $10^{-2} \mathrm{M}$ Chloramphenicol succinate was adjusted with dilute solutions of sodium hydroxide and hydrochloric acid.

$$
\begin{aligned}
\log \mathrm{K}^{\mathrm{pot}}= & {[(\mathrm{EB}-\mathrm{EA}) /(2.303 \mathrm{RT} / \mathrm{zF})]+(1-\mathrm{zA} / \mathrm{zB}) } \\
& \operatorname{logaA} \ldots \ldots \ldots \ldots \ldots \ldots \ldots \ldots \ldots \ldots \ldots \ldots \ldots \ldots \ldots \ldots \ldots \ldots \ldots \ldots \ldots \ldots \ldots \ldots \ldots \ldots \ldots \ldots \ldots \ldots \ldots
\end{aligned}
$$

$\mathrm{EA}, \mathrm{EB} ; \mathrm{zA}, \mathrm{zB}$; and $\mathrm{aA}, \mathrm{aB}$ are the potentials, charge numbers, and activities for the primary A and interfering $B$ ions, respectively, at $\mathrm{aA}=\mathrm{aB}$.

\section{Selectivity measurements}

A separate solution method was used for the selectivity coefficient measurement, and was calculated according to the equation (1) [16].

The selectivity coefficients were also measured by the mixed solution method according to the equation (2) [17]

$\mathrm{K}^{\mathrm{pot}}=\Delta \mathrm{aA} / \mathrm{aB} \quad \Delta \mathrm{aA}=\mathrm{aA}-\mathrm{aA}$ $\mathrm{K}^{\text {pot }} \mathrm{AB}=\mathrm{aA} / \mathrm{aBzA} / \mathrm{zB}$

\section{Results and Discussion}

Response characteristics of prepared Chloramphenicol succinate are summarized in Table (1). Performances of electrodes prepared using an ion-pair complex as an electractive material and different plasticizers were compared experimentally. 
Table (1)

Response characteristics of CPSS - PMA selective electrodes using different plasticizers.

\begin{tabular}{||c||c||c||c|c||}
\hline $\begin{array}{c}\text { Membrane } \\
\text { Composition }\end{array}$ & $\begin{array}{c}\text { CPSS-PMA } \\
+ \text { DOPH } \\
(I)\end{array}$ & $\begin{array}{c}\text { CPSS-PMA } \\
+ \text { TBP } \\
(I I)\end{array}$ & $\begin{array}{c}\text { CPSS-PMA } \\
+ \text { ONPOE } \\
(I I I)\end{array}$ & $\begin{array}{c}\text { CPSS-PMA } \\
+ \text { DBPH } \\
(I V)\end{array}$ \\
\hline $\begin{array}{c}\text { Slope } \\
\text { mV/decade }\end{array}$ & 58.5 & 48.9 & 46.4 & 53.9 \\
\hline $\begin{array}{c}\text { Linearity } \\
\text { Range/M }\end{array}$ & $1 \times 10^{-4}-1 \times 10^{-1}$ & $5 \times 10^{-4}-1 \times 10^{-1}$ & $8 \times 10^{-4}-1 \times 10^{-1}$ & $2 \times 10^{-4}-1 \times 10^{-1}$ \\
\hline $\begin{array}{c}\text { Correlation } \\
\text { coefficient }\end{array}$ & 0.9999 & 0.9998 & 0.9996 & 0.9999 \\
\hline $\begin{array}{c}\text { Detection } \\
\text { Limit/M }\end{array}$ & $5.0 \times 10^{-6}$ & $4.0 \times 10^{-5}$ & $2.0 \times 10^{-5}$ & $5.0 \times 10^{-5}$ \\
\hline Life time/day & 40 & 15 & 7 & 25 \\
\hline
\end{tabular}

The complex was incorporated into a PVC membrane with the following plasticizers: dioctyl phthalate (membrane I), tri-n-butyl phosphate (membrane II), o-nitro phenyl octyl ether (membrane III), and di-n-butyl phthalate (membrane IV). The working characteristics for the electrodes were assessed on the basis of their calibration curves. The physical properties of these membranes were as follows: white, flexible, clear, and transparent (non-crystalline). The slops are 58.5, 48.9, 46.4 and $53.9 \mathrm{mV} /$ decade, respectively.

The correlation coefficients were 0.9999 , 0.9998, 0.9996 and 0.9999 respectively. NonNernstian slopes were obtained for electrodes based on TBP and ONPOE (membranes II and III). The linear range and detection limits for the two electrodes were $\left(1.0 \times 10^{-1}\right.$ to $\left.5.0 \times 10^{-4}\right)$ $\mathrm{M}, 4.0 \times 10^{-5} \mathrm{M}$ and $\left(8.0 \times 10^{-4}\right.$ to $\left.1.0 \times 10^{-1}\right) \mathrm{M}$, $2.0 \times 10^{-5} \mathrm{M}$ respectively.

The non-Nernstian slope behaviors could be attributed to the low viscosity of ONPOE (11.44 cST), or incompatibility of the plasticizer with the complex in PVC. The TBP, which has a low viscosity (3.11 cST), leads to leaching of the complex from the membrane or may have a high steric effect on alkel groups. Near Nernstian slopes were obtained for the electrodes based on DOPH and DBPH (membranes I and IV). A typical calibration plot for electrodes II and IV are shown in Fig.(1).
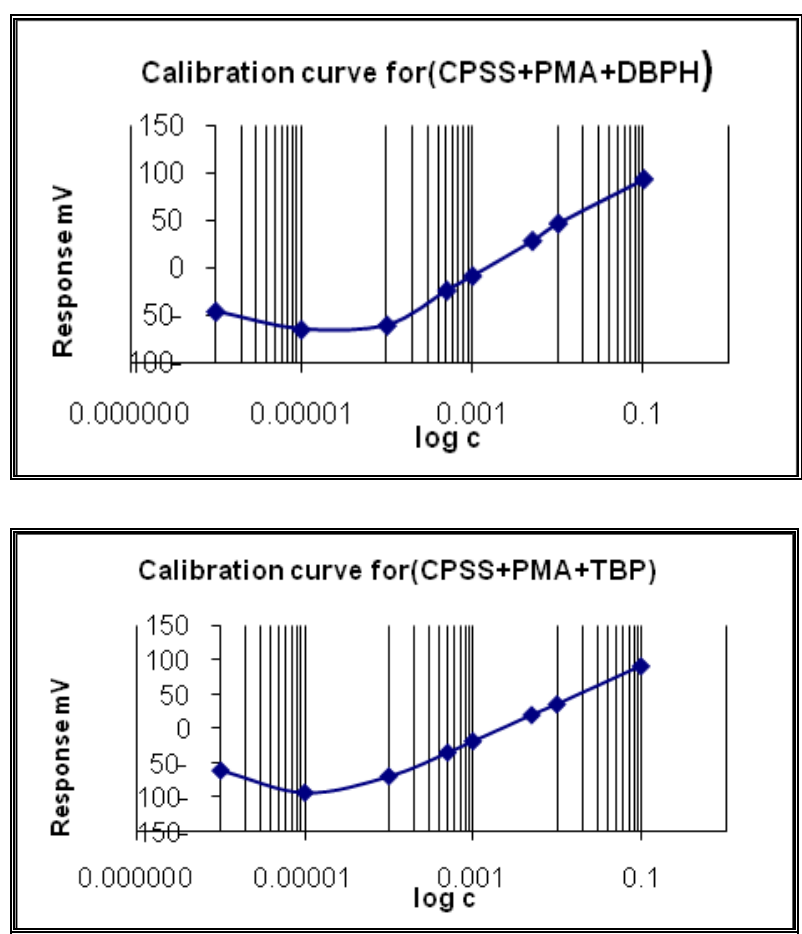

Fig.(1) Calibration curves of

Chloramphenicol succinate selective electrodes. DBPH, TBP.

Electrode parameters for DOPH as a plasticizer gave a good response. The electrode had good stabilityand was used for the quantitative determination of pharmaceutical drugs.

\section{Effect of pH}

The effect of $\mathrm{pH}$ on the electrode potentials for (CPSS) selective membrane electrodes were examined by measuring the e.m.f. of the cell in (CPSS) solutions at three different concentrations $\left(10^{-4}, 10^{-3}, 10^{-2}\right) \mathrm{M}$ in which the $\mathrm{pH}$ ranged from (1.8-10.4). The 
working $\mathrm{pH}$ were tabulated in Table (2). And typical plot of $\mathrm{pH}$ effect on electrode response for electrode based on DBPH is shown in Fig.(2).

The effect of $\mathrm{pH}$ on the response of the $\mathrm{pH}$ was adjusted by adding few drops of ammonia and hydrochloric acid solutions.

Table (2)

Working pH ranges for Chloramphenicol succinate selective electrodes.

\begin{tabular}{|c|c|c|c|c|}
\hline \multirow{2}{*}{ Number } & \multirow{2}{*}{$\begin{array}{l}\text { Membrane } \\
\text { Composition }\end{array}$} & \multicolumn{3}{|c|}{ pH range } \\
\hline & & $1 \times 10^{-2}$ & $1 \times 10^{-3}$ & $1 \times 10^{-4}$ \\
\hline$I$ & $\begin{array}{c}\text { CPSS-PMA } \\
+D O P H\end{array}$ & $\begin{array}{c}2.1- \\
8.9\end{array}$ & $\begin{array}{c}2.5- \\
8.6\end{array}$ & $\begin{array}{c}2.1- \\
9.8\end{array}$ \\
\hline II & $\begin{array}{c}C P S S-P M A \\
+T B P\end{array}$ & $\begin{array}{c}1.9- \\
8.8\end{array}$ & $\begin{array}{c}2.1- \\
9.8\end{array}$ & $\begin{array}{c}2.0- \\
9.2\end{array}$ \\
\hline III & $\begin{array}{c}\text { CPSS - PMA } \\
\text { + ONPOE }\end{array}$ & $\begin{array}{c}1.8- \\
8.6\end{array}$ & $\begin{array}{c}2.4- \\
9.4\end{array}$ & $\begin{array}{c}2.3- \\
9.5\end{array}$ \\
\hline$\overline{I I V}$ & $\begin{array}{c}C P S S- \\
P M A+B P H\end{array}$ & $\begin{array}{c}2.0- \\
9.4\end{array}$ & $\begin{array}{c}2.1- \\
9.6\end{array}$ & $\begin{array}{c}2.2- \\
10.4\end{array}$ \\
\hline
\end{tabular}

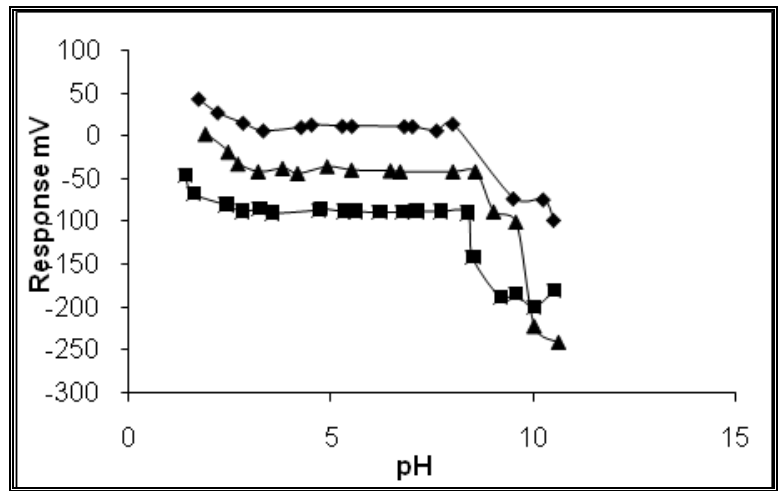

Fig. (2) Effect of pH on the potential of the Chloramphenicol succinate electrodes at concentrations

(ロ 10-2, $\triangle 10-3$ and $\$ 10-4) M$.

\section{Response time}

The response time at $\mathrm{t} 95$ for all the electrodes at concentrations ranging from $\left(10^{-6}\right.$ to $\left.10^{-1}\right) \quad M$ was calculated from the response versus time plot and is listed in Table (3).
Table (3)

Response time of Chloramphenicol succinate electrodes.

\begin{tabular}{|c||c||c||c|c||}
\hline $\begin{array}{c}\text { Conc. } \\
(\mathbf{M})\end{array}$ & $\begin{array}{c}\text { Electrode } \\
\text { I } \\
(\mathbf{s e c})\end{array}$ & $\begin{array}{c}\text { Electrode } \\
\text { II } \\
(\mathbf{s e c})\end{array}$ & $\begin{array}{c}\text { Electrode } \\
\text { III } \\
(\mathbf{s e c})\end{array}$ & $\begin{array}{c}\text { Electrode } \\
\text { IV } \\
(\mathbf{s e c})\end{array}$ \\
\hline \hline $10^{-1}$ & 10 & 12 & 17 & 11 \\
\hline \hline $10^{-2}$ & 14 & 20 & 18 & 21 \\
\hline \hline $10^{-3}$ & 18 & 25 & 23 & 21 \\
\hline \hline $10^{-4}$ & 21 & 32 & 30 & 24 \\
\hline \hline $10^{-5}$ & 21 & 30 & 35 & 27 \\
\hline \hline $10^{-6}$ & 25 & 32 & 33 & 29 \\
\hline
\end{tabular}

As shown, the longer response time reached around $35 \mathrm{~s}$ at $10-5 \mathrm{M}$. All the electrodes gave the same range of response times.

\section{Selectivity}

The influence of some inorganic cations on the response of Chloramphenicol succinate electrods was investigated. Potentiometric selectivity can be measured with separate solution method, the selectivity of the electrodes based on DBPH and ONPOE as measured by the separate solution method for a concentration range from $10^{-6}$ to $10^{-1} \mathrm{M}$. The potentiometric selectivity coefficients were calculated using equation (1) at cation concentrations ranging between $\left(10^{-6}\right.$ and $10^{-1}$ ) M. A typical plot is shown in Fig.(3) for the interference of $\mathrm{Fe}^{3+}$ on the $\mathrm{DBPH}$ electrode. The values of the selectivity coefficients for DBPH and ONPOE electrodes are listed in Table (4). The selectivity coefficients were very small. This means that there is no interference of these cations with the response of Chloramphenicol succinate electrodes. The order of selectivity was: Mono-valent > Di-valent > Tri-valent ions. Selectivity coefficients for ONOEP and DBPH as the plasticizers were also calculated by a separate solution method. 


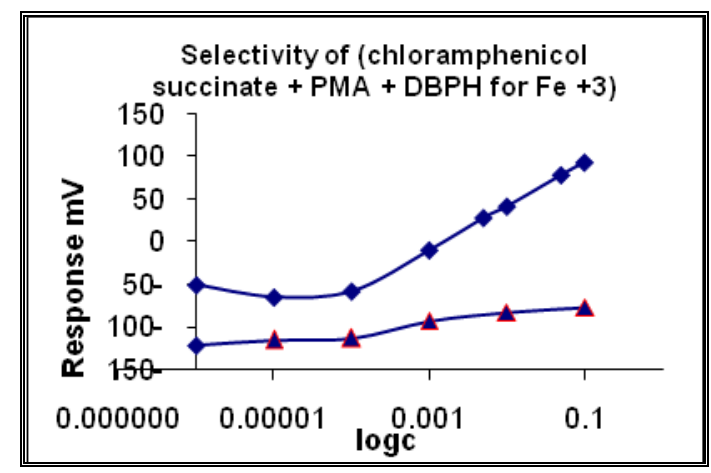

Fig. (3) Selectivity of (CPSS - PMA + $D B P H) I V$ and the interfering cation $\left(F^{3+}\right)$ by separation method, $\diamond$ Chloramphenicol succinate, $\Delta$ Solution of interfering cation $\left(\mathrm{Fe}^{3+}\right)$.

Table (4)

Selectivity Coefficients for (CPSS-PMA+DBPH) IV electrodes at different concentrations by separation method.

\begin{tabular}{|c|c|c|c|c|c|c|}
\hline \multirow{3}{*}{$\begin{array}{l}\text { Interfering } \\
\quad \text { ions }\end{array}$} & \multicolumn{6}{|c|}{ Concentrations of Chloramphenicol succinate (M) } \\
\hline & $10^{-1}$ & $10^{-2}$ & $10^{-3}$ & $10^{-4}$ & $10^{-5}$ & $10^{-6}$ \\
\hline & $K_{A, B}$ & $K_{A, B}$ & $K_{A, B}$ & $K_{A, B}$ & $K_{A, B}$ & $K_{A, B}$ \\
\hline $\mathrm{Li}^{+}$ & $1.23 \times 10^{-3}$ & $2.34 \times 10^{-3}$ & $1.78 \times 10^{-3}$ & $2.31 \times 10^{-2}$ & $2.25 \times 10^{-2}$ & $2.18 \times 10^{-2}$ \\
\hline$K^{+}$ & $1.38 \times 10^{-3}$ & $1.56 \times 10^{-3}$ & $1.43 \times 10^{-2}$ & $3.19 \times 10^{-1}$ & $2.66 \times 10^{-1}$ & $3.99 \times 10^{-2}$ \\
\hline $\mathrm{Ca}^{2+}$ & $1.45 \times 10^{-4}$ & $4.34 \times 10^{-5}$ & $3.67 \times 10^{-5}$ & $2.55 \times 10^{-4}$ & $3.37 \times 10^{-5}$ & $2.08 \times 10^{-5}$ \\
\hline $\mathrm{Mg}^{2+}$ & $1.65 \times 10^{-4}$ & $2.10 \times 10^{-4}$ & $2.56 \times 10^{-4}$ & $3.22 \times 10^{-4}$ & $4.26 \times 10^{-5}$ & $3.29 \times 10^{-6}$ \\
\hline$A l^{3+}$ & $2.12 \times 10^{-5}$ & $2.99 \times 10^{-5}$ & $2.65 \times 10^{-5}$ & $2.87 \times 10^{-4}$ & $3.22 \times 10^{-5}$ & $4.03 \times 10^{-6}$ \\
\hline$F e^{3+}$ & $2.45 \times 10^{-4}$ & $3.91 \times 10^{-3}$ & $2.78 \times 10^{-2}$ & $3.12 \times 10^{-2}$ & $4.92 \times 10^{-2}$ & $4.77 \times 10^{-2}$ \\
\hline
\end{tabular}

Table (5)

Selectivity Coefficients for (CPSS-PMA+ONOEP) III electrodes at different concentrations by separation method.

\begin{tabular}{|c|c|c|c|c|c|c|}
\hline \multirow{3}{*}{$\begin{array}{c}\text { Interfering } \\
\text { ions }\end{array}$} & \multicolumn{6}{|c|}{ Concentrations of Chloramphenicol succinate $(M)$} \\
\hline & $10^{-1}$ & $10^{-2}$ & $10^{-3}$ & $10^{-4}$ & $10^{-5}$ & $10^{-6}$ \\
\hline & $K_{A, B}$ & $K_{A, B}$ & $K_{A, B}$ & $K_{A, B}$ & $K_{A, B}$ & $K_{A, B}$ \\
\hline $\mathrm{Li}^{+}$ & $4.87 \times 10^{-9}$ & $4.99 \times 10^{-7}$ & $4.77 \times 10^{-5}$ & $4.51 \times 10^{-3}$ & $5.54 \times 10^{-2}$ & $5.99 \times 10^{-1}$ \\
\hline$K^{+}$ & $2.93 \times 10^{-8}$ & $6.93 \times 10^{-7}$ & $5.92 \times 10^{-5}$ & $4.73 \times 10^{-3}$ & $4.54 \times 10^{-2}$ & $2.88 \times 10^{-1}$ \\
\hline $\mathrm{Ca}^{2+}$ & $6.63 \times 10^{-2}$ & $4.55 \times 10^{-1}$ & $4.55 \times 10^{-2}$ & $3.66 \times 10^{-1}$ & $3.91 \times 10^{-1}$ & $4.52 \times 10^{-1}$ \\
\hline $\mathrm{Mg}^{2+}$ & $3.93 \times 10^{-5}$ & $2.55 \times 10^{-4}$ & $5.39 \times 10^{-4}$ & $3.13 \times 10^{-3}$ & $5.93 \times 10^{-4}$ & $7.66 \times 10^{-4}$ \\
\hline$A l^{3+}$ & $2.79 \times 10^{-2}$ & $2.32 \times 10^{-2}$ & $2.88 \times 10^{-2}$ & $2.94 \times 10^{-2}$ & $2.86 \times 10^{-2}$ & $2.59 \times 10^{-3}$ \\
\hline$F e^{3+}$ & $4.02 \times 10^{-7}$ & $3.08 \times 10^{-5}$ & $4.44 \times 10^{-4}$ & $3.01 \times 10^{-2}$ & $4.31 \times 10^{-1}$ & $4.19 \times 10^{-1}$ \\
\hline
\end{tabular}

The selectivity coefficients indicate good selectivity for Chloramphenicol succinate against some common transition metal ions. Moreover, the selectivity coefficient for monovalent ions is lower than that for divalent ions. This may be due to the differences in ionic size, mobility and permeability.

\section{Sample Analyses:}

Three potentiometric techniques were used for the determination of (CPSS) including. Direct method, Standard addition method (SAM), follows the equation: 


$$
\mathrm{C}_{\mathrm{U}}=\frac{\mathrm{C}_{\mathrm{S}}}{10^{\Delta \mathrm{E} / \mathrm{s}}}\left(1+\frac{\mathrm{V}_{\mathrm{U}}}{\mathrm{V}_{\mathrm{S}}}\right)-\frac{\mathrm{V}_{\mathrm{U}}}{\mathrm{V}_{\mathrm{S}}}
$$

Where $\mathrm{C}_{\mathrm{U}}, \mathrm{C}_{\mathrm{S}}, \mathrm{V}_{\mathrm{U}}$ and $\mathrm{V}_{\mathrm{S}}$ are the concentration and volume of unknown and standard solution respectively multiple Standard additions (MSA) [18,19]. carried as in Fig.(4). Synthetic solutions of
Chloramphenicol succinate at concentrations between $\left(10^{-5}\right.$ and $\left.10^{-3}\right) \mathrm{M}$ were used for the standard addition method using DOPH and ONPOE electrodes. The \%RSD, \% RC, and \% $\mathrm{RE}$ were calculated and are listed in table (7).

Table (7)

Determination of Chloramphenicol succinate -ion samples by potentiometric techniques.

\begin{tabular}{|c|c|c|c|c|}
\hline \multirow{3}{*}{ Electrode No. } & \multicolumn{4}{|c|}{ Concentrations (M) } \\
\hline & \multirow{2}{*}{ Sample } & \multicolumn{3}{|c|}{ Measurements using potentiometric methods } \\
\hline & & Direct & $S A M$ & MSA \\
\hline \multirow{8}{*}{$\begin{array}{c}\text { CPSS- PMA+ } \\
\text { DBPH }\end{array}$} & $1 \times 10^{-3}$ & $0.985 \times 10^{-3}$ & $1.008 \times 10^{-3}$ & $1.002 \times 10^{-3}$ \\
\hline & RSD\% & $2.3^{*}$ & $1.42^{*}$ & 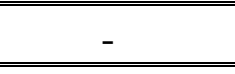 \\
\hline & $\mathrm{RC} \%$ & 98.5 & 100.8 & 100.2 \\
\hline & RE\% & 1.5 & 0.8 & 0.2 \\
\hline & $1 \times 10^{-4}$ & $0.991 \times 10^{-4}$ & $1.006 \times 10^{-4}$ & $0.998 \times 10^{-4}$ \\
\hline & RSD\% & $3.01^{*}$ & $1.25^{*}$ & - \\
\hline & $\mathrm{RC} \%$ & 99.1 & 100.6 & 99.8 \\
\hline & $\mathrm{RE} \%$ & -0.9 & 0.4 & -0.2 \\
\hline \multirow{8}{*}{$\begin{array}{l}\text { CPSS- PMA + } \\
\text { ONOEP }\end{array}$} & $1 \times 10^{-3}$ & $1.051 \times 10$ & $0.988 \times 10^{-3}$ & $1.010 \times 10^{-3}$ \\
\hline & RSD\% & $1.23^{*}$ & $1.01^{*}$ & - \\
\hline & $\mathrm{RC} \%$ & 105.1 & 98.8 & 101.0 \\
\hline & RE\% & 5.1 & -2.2 & 1.0 \\
\hline & $1 \times 10^{-4}$ & $0.985 \times 10^{-4}$ & $0.975 \times 10^{-4}$ & $1.014 \times 10^{-4}$ \\
\hline & RSD\% & $2.03^{*}$ & $1.28^{*}$ & 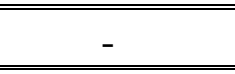 \\
\hline & $\mathrm{RC} \%$ & 98.5 & 97.5 & 101.4 \\
\hline & $\mathrm{RE} \%$ & -1.5 & 2.5 & 1.4 \\
\hline
\end{tabular}

* Each measurement was repeated three times.

The plot of antilog E/S versus the volume of the five addition for $0.1 \mathrm{~mL}$ of $1 \times 10^{-1} \mathrm{M}$ standard Chloramphenicol succinate solution to the $1 \times 10^{-3} \mathrm{M}$ Chloramphenicol succinate is shown in Fig.(4). 


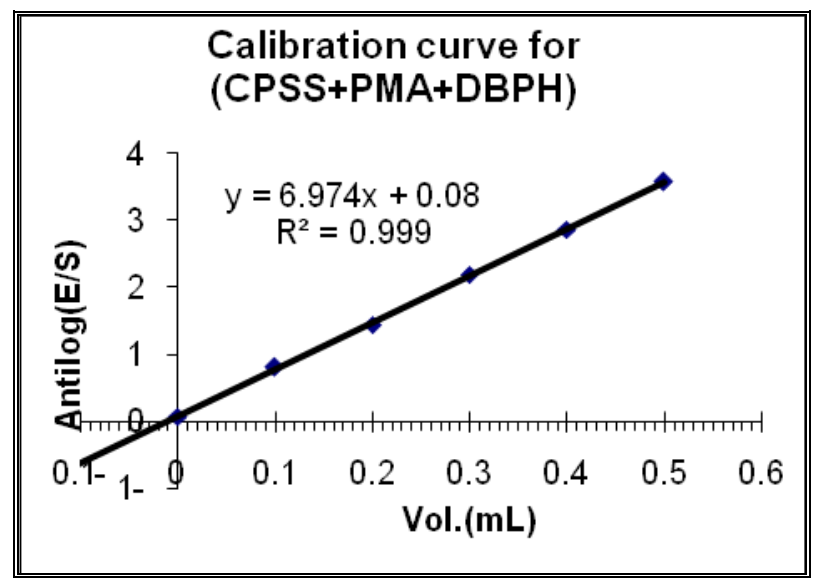

Fig. (4) Plot antilog (E/S) versus the value of the added standard for the determination of Chloramphenicol succinate solution $\left(10^{-4} \mathrm{M}\right)$ by MSA using CPSS-PMA+DBPH electrode.

The results in Table (1) showed that the electrodes based on DOPH and DBPH as a plasticizer were the best electrodes.

The direct potentiometric method was applied for the determination of Chloramphenicol succinate in pharmaceutical injection and tablets (Epanutin from samara, Germany and USA) as listed in table (8) using the electrode based on membrane (IV).

Table (8)

Sample analysis for tablets using the Chloramphenicol succinate selective electrode based on DBPH plasticizer using the direct potentiometric method.

\begin{tabular}{|c||c||c||c||}
\hline Pharmaceuticl & $\begin{array}{c}\text { Epanutin } \\
\text { (samara) }\end{array}$ & $\begin{array}{c}\text { Epanutin } \\
\text { (Germany) }\end{array}$ & $\begin{array}{c}\text { Epanutin } \\
\text { (USA) }\end{array}$ \\
\hline $\begin{array}{c}\text { Concentration of } \\
\text { Chloramphenicol } \\
\text { succinate } \\
\text { (prepared)/M }\end{array}$ & $1 \times 10^{-3}$ & $1 \times 10^{-3}$ & $1 \times 10^{-3}$ \\
\hline $\begin{array}{c}\text { Concentration of } \\
\text { Chloramphenicol } \\
\text { succinate } \\
\text { (found)/M }\end{array}$ & $0.985 \times 10^{-3}$ & $0.998 \times 10^{-3}$ & $0.982 \times 10^{-3}$ \\
\hline \hline \%recovery & 98.5 & 99.8 & 98.2 \\
\hline \hline \%RE & 1.5 & 0.2 & -1.8 \\
\hline \hline \%RSD & 1.23 & 1.46 & 1.02 \\
\hline \hline
\end{tabular}

\section{References}

[1] "British Pharmacopoeia on CD-Rom" The Stationery Office on behalf of the Medicines and Healthcare products Regulatory Agency (MHRA). London. 5th, ed., 2007.
[2] Falagas, M. E.; Michalopoulos, A. A.; "Potential of old-generation antibiotics to address current need for new antibiotics"; Expert Rev Anti Infect Ther., 6, 2008, pp.593-600.

[3] Wilson, A.; Schild, H. O.; Modell, W.; "Applied Pharmacology"; 11th Ed., Churchill Livingstone, London, 1975.

[4] Official Methods of Analysis AOAC International, 16th ed., vol. 2, Capth 33.

[5] Analytical Profiles of Analytical Substances, vol.5, Klaus Florey, Academic Press, San Diego, CA, 1989.

[6] Morelli, B., "Spectrophotometric assay for chloramphenicol and some derivatives in the pure form and in formulations" $J$. Pharm. Biomed. Anal. 5, 1987, pp:577.

[7] Abdel Hamid, M.E.; Abuirjeie, M.A., "Spectrophotometric determination of chloramphenicol using orthogonal polynomials" Analyst 112, 1987, pp:895.

[8] Sastry, C.S.P.; Divakar, T.E. and Prasad, U.V., "Indirect spectrophotometric methods for the determination of antibiotics with iodine or periodate, and metol and sulphanilamide", Talanta 33, 1986, pp164.

[9] Mulhall A., de Louvois J., Hurley R. "The efficacy of chloramphenicol in the treatment of neonatal and infantile meningitis; a study of 70 cases". Lancet, i, 1983, pp:284-7.

[10] Sutherland J.M., "Fatal cardiovascular collapse of infants receiving large amounts of chloramphenicol". Am. J. Dis. Child, 97, 1959, pp: 761-7.

[11] Scott J.L., Finegold S.M., Belkin G.A., Lawrence J.S. "A controlled double blind study of the haematologic toxicity of chloramphenicol", $\mathrm{N}$ Engi J. Med., 272(1), 1965, pp:137-42.

[12] Yunis A.A., Bloomberg G.R. "Chloramphenicol toxicity: clinical features and pathogenesis". Prog. Hematol 4, 1964, pp:138.

[13] Craft A.W., Brocklebank J.T., Hey E.N., Jackson R.H. "The "grey-toddler." Chloramphenicol toxicity". Arch. Dis. Child, 49, 1974. pp:235-7. 
[14] Slaughter R.L., Pieper J.A., Cerra F.B., Brodsky B., Koup J.R. "Chloramphenicol sodium succinate kinetics in critically ill patients", Clin. Pharmacol. Ther., 28, 1980, pp:69-77.

[15] Mahajan R. K., Kaur R., Kaur I., Sharma V. and Kumar M., "Novel Copper (II)Selective electrode based on 2,2: 5,2 "terthiophene in PVC Matrix", Anal. Sci., 20, 2004, pp:811.

[16] Umezawa, Y.; Umezawa, K. and Sato, H., "selectivity Coefficients for Ion selective electrodes", pure Apple. Chem., 67, 1995, pp:508-518.

[17] Umezawa, Y.; Umezawa, K.; Bhlmann, P.; Tohda, K. and Amemiya, S., "potentiometry Selectivity Coefficients of Ion-Selective electrode", pure and Appl. Chem., 72(10), 2000, pp:1851-2082.

[18] Didarul, A. C., Takashi, O. S., Atsuo, K., and Kousaburo, O., Anal. Chem. 68, 1996, pp:366.

[19] Rundl Ch. C., "A Beginners Guide to Ion Selective Electrodes Measurement". Nico 2000 Ltd. London, UK. (2004).

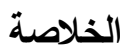

تم تحضير أقطاب انتقائية لدواءكلورومينفكول سكسنيت

بتكوين معقد مع الليكاند حامض الفوسفومولبديت كمادة فعالة باستخدام ملدنات متعددة منها لبهات

Di-octylphthalate (DOPH), Tri-butyl phosphate (TBP), O-nitrophenyloctylether (ONPOE), Di-butyl phthalate (DBPH)

$$
\begin{aligned}
& \text { تم دراسة خواص هذه الاقطاب ومنها الميل، }
\end{aligned}
$$

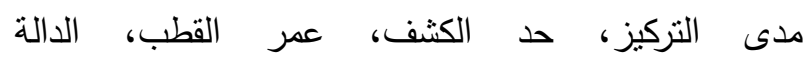

$$
\begin{aligned}
& \text { الحامضية والانتقائية الايونية. ومن خلائ النتائج } \\
& \text { لوحظ ان افضل قطبين تم الحصول عليها هما القطبين } \\
& \text { الحاويين على الملدنات DOPH و DBPH حيث لوحظ } \\
& \text { مدى التركيز لهما 1.0×10×1-4 - }
\end{aligned}
$$

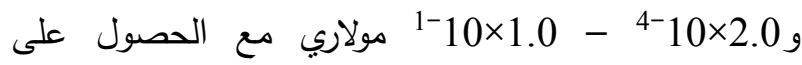

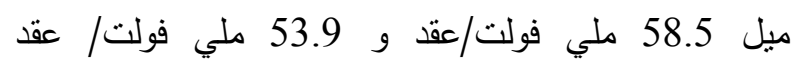

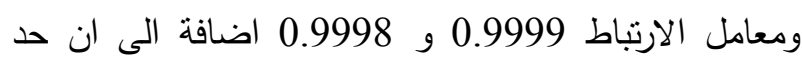

$$
\begin{aligned}
& \text { الكثف يتراوح بين 5.5×10-5 -5.0 - } \\
& \text { بالنسبة لعمر القطب فكان الاول } 40 \text { يوم والثاني } 25 \text { يوم هذه دئ دولاني }
\end{aligned}
$$

الاقطاب المحضرة تم تطبيقها بنجاح في تعيين كلورومينفكول

سكسنيت في الادوية التجارية. 